\title{
POLITICAL PRISONERS IN FRENCH MENTAL INSTITUTIONS BEFORE 1789, DURING THE REVOLUTION, AND UNDER NAPOLEON I
}

\author{
by
}

\section{ERWIN H. ACKERKNECHT*}

BEFORE 1789 mental patients were interned in France in three types of institutions: the state-directed hôpital général, the clerical institution (often called charité), and the small private pension, maison de santé.

Hôpital général is a misnomer and a euphemism. In Germany at that time these institutions were far more appropriately called Zuchthäuser, in England "workhouses", and in certain French towns dépôts de mendicité. ${ }^{1}$ The hôpital général was absolutism's answer to the social problem. The king's edict of 1656, which created this type of institution, was primarily an (ineffective) remedy for the beggar problem. The Pitié in Paris had been transformed before 1656 into a beggars' prison and workhouse. Hôpitals generals had been established by decree in Toulouse (1647), Beziers (1654), and Caen (1655). But le grand renfermement des pauvres in Paris in 1656 was to decide the trend. ${ }^{2}$ Beggars and all other socially undesirable individuals were now interned in these large institutions. As George Rosen says, "A separate socio-psychological life space was created for those who removed themselves from or transgressed the moral order, considered appropriate to their social position, occupation or family relationship."3

The population of the Bicêtre and Salpetrière, the main divisions of the Paris general hospital (the former for men and the latter for women), was composed during the 150 years of their existence of a few thousand working "beggars", young and old; a few hundred old and invalid people, unable to work; a few hundred children (orphans or delinquents); a few hundred mentally ill people; a few hundred sick people (particularly those suffering from venereal and skin diseases), and a few hundred criminals. Therefore it was quite natural that some political prisoners (including "heretics" and some of the so-called libertins) would be found among the hospital's inmates." We must realize that, under the ancient regime, people with political convictions such as Mirabeau, Diderot, Brissot, etc., were rare among the political prisoners. The majority were unknown individuals who owed their captivity (as in all dictatorships) to a few critical remarks, a joke at the king or his mistresses-and a denunciation. The deep sufferings of internment may still be aggravated by the forced company of abnormal and insane persons. Some of the inmates of the hopital général would, by the way, be voluntary patients, a sad reflection on economic conditions outside the prisons. ${ }^{5}$ Under the circumstances it is understandable that a political prisoner like Latude could be shifted from "pure" prisons like Vincennes or

*Erwin H. Ackerknecht, M.D., is Professor of the History of Medicine, University of Zürich, CH 8006 Zürich, Ottikerstrasse 42, Switzerland. 


\section{Political prisoners in French mental institutions}

the Bastille to "mixed" institutions like Bicêtre or Charenton, or Tiercelin from St. Yon and St. Lazare to Vincennes. ${ }^{6}$

Even when such divisions of the hôpital général as Bicêtre and Salpetrière were more and more limited to the function of psycho-geriatric asylums, they still harboured criminals and political prisoners like the Abbé Marie Nicolas Fournier, later bishop of Montpellier, who was interned in the insane division of Bicêtre in $1801 .^{7}$ The divisions for criminals were abolished in the Salpetrière in 1795, in Bicêtre only in 1836.

The second type of institution for the insane before 1789 comprised those founded and administered by the church, sometimes monasteries, sometimes ad hoc foundations. For Paris we may mention St. Lazare and Charenton; for the provinces La Charité de Senlis, Château Thierry, St. Yon, Pontarson, Cadillac, Romans, Marseilles, Caën, Rennes, Clermont-sur-Oise, etc. ${ }^{8}$ Intended primarily as hospitals, these institutions financed the care of the poor by serving as prison for the so-called correctionnaires, and in fact harboured a similar mixture of invalid or diseased people and criminals as found in the general hospitals. The name charité sounds somewhat hollow in view of their realities, and it is difficult to understand how P. Sérieux and his school could praise these institutions as expressions of the enlightened care of lunatics under the ancien régime. The correctionnaires were either state or church prisoners, thus occasionally political prisoners; or prisoners whose families had obtained a lettre de cachet and preferred to pay for the maintenance of their black sheep here in order to keep them out of court or circulation. At times the correctionnaires protested against their coexistence with lunatics in these institutions. ${ }^{9}$

St. Lazare, for instance, was populated by clerics, by mentally diseased people, and by the so-called libertins, sorcerers, abortionists, pornographers, adulterers, spendthrifts, Jansenists, and protestants. ${ }^{10}$ Not accidentally did its founder, St. Vincent de Paul, call his house, where everybody entering was submitted to flagellation, ${ }^{102}$ a "Noah's ark". After the Revolution, St. Lazare became a prison for females and infected prostitutes. Charenton was officially an asylum as well as a state prison from 1720 to $1781 .{ }^{11}$ In the Charite de Senlis the ratio of lunatics to correctionnaires was $86: 34$. Among the reasons for internment of the latter we find: intrigues with foreign powers; subversive talk. ${ }^{12}$ There seems to be no doubt that in the clerical institutions as well as in the general hospitals political prisoners were repeatedly interned.

Of the third type of mental institution, the maison de santé (sometimes called petites maisons or pensions bourgeoises), Bonnafous claims that eighteen existed in Paris alone before $1789 .{ }^{13}$ We know by name the houses of Belhomme (Rue de Charonne), Dubuisson (Fbg St. Antoine), Demoiselles Donay et Lacour (Rue Nouvelle France), Mme Ste. Colombe (Fbg St. Antoine), Chirurgien Escourbiac (Rue du Chemin Vert), ${ }^{14}$ Coignard (Picpus), Brunet (Rue Buffon), La Chapelle (Rue Folie Regnault), Lemoine (Rue des Amandiers), Desnos dit Montprin (Rue Notre Dame des Champs). ${ }^{15}$ Though generally founded by individuals without a medical background, they come nearest to what we would regard today as psychiatric institutions insofar as the composition and treatment of patients was concerned. A criminal might occasionally be concealed here from the courts, e.g. the famous St. Just, when he had stolen his mother's silver, spent some time (1786-1787) in the Maison de Santé de Mme Ste. Colombe, Fbg St. Antoine. ${ }^{16}$ 


\section{E. H. Ackerknecht}

From the number of these institutions it is possible to assume that a considerable portion, perhaps as high as one-third, of the interned mental cases in Paris lived in maisons de santé. Though the politician Tallien emphatically stated 'Il existe à Paris une multitude de ces maisons connues sous le nom de pensions bourgeoises, où l'on tient renfermés sous pretexte de folie une foule de citoyens et citoyennes arrêtés en vertu d'ordre arbitraires", ${ }^{17}$ we have found no specific references to political prisoners in them before the Revolution. A physician or surgeon might sometimes look after these patients, especially their physical complaints, but it is extremely significant that all internments in all types of institution were decided by the police or magistrates without official medical opinion.

\section{DURING THE REVOLUTION}

In 1790 the Constituante decreed the liberation of all internees except lunatics and committed criminals. However, the political upheaval gave rise to a great number of political prisoners and an increased need for prisons. Thus Salpetrière and Bicêtre accommodated political prisoners with lunatics, as is sadly evident from the September massacres of 1792 or the use of Bicêtre for the prisoners of the revolutionary court in 1794. The religious institutions, insofar as they were not transformed completely into prisons like St. Lazare, remained "mixed". Probably the greatest change occurred in the maisons de santé which became to a large extent auxiliary prisons. Extensive documentary evidence exists concerning the Maison Belhomme. ${ }^{18}$

The Maison Belhomme has become famous as the place where Pinel started his psychiatric career. It was also the scene of one of the strangest affairs of corruption during the Revolution. ${ }^{19}$ Jacques Belhomme, born in 1737 at Mesnil-Conteville, worked as a cabinetmaker at 157 Rue de Charonne. In 1768 he founded an institution for the insane at 159 Rue de Charonne. It was a bona fide institution with forty-six inmates in 1789. In this small private institution, intended for the wealthy, Pinel worked from 1783 to 1788 as a consultant, and developed the ideas which he was later to apply on a large scale at Bicêtre and Salpetrière.

At the outbreak of the Revolution Belhomme became an officer of the national guard and a model patriot. Thus he became connected with officers of the revolutionary tribunal, and "sick prisoners" were sent to him, especially after 1793, to such an extent that the number of his inmates increased to 200 . Superficially there was no difference from other sanatoria-prisons; but a transfer to Belhomme's house saved a prisoner's life. Belhomme seems to have shared with somebody in authority the exorbitant sums he squeezed out of his dukes, duchesses, counts and countesses, so that they could avoid the guillotine. Among aristocrats who thus survived were the Duchess of Orleans; the widow of Philippe-Egalité; the widow of Petion; the comtes de Roure, de Breteuil, de Rochechouart, de Ranconnet; Talleyrand; Volney; and the famous actresses Mlles Lange and Mezeray. Those who could no longer pay, like Linguet and the duchesses of Choiseul and Chatelet, were sent back to the Conciergerie, judged there immediately, and executed.

Belhomme was arrested in 1794 and condemned to four years' hard labour for extortion. He remained only nine months in prison. The business meanwhile went on under his wife's direction. In 1795 his prisoners were transferred to other maisons 


\section{Political prisoners in French mental institutions}

de santé, also harbouring prisoners. The Maison Belhomme became a psychiatric institution again after his return, but not for long. From 1803 until 1820 it served partly as a prison, especially for spies. Belhomme died in 1824 and was followed as director by his son, Dr. Jacques-Etienne Belhomme (1800-1880), who continued until 1852. The latter had served under Pinel and Esquirol, who became his consultant, and graduated in 1824 with a thesis on idiocy, which made him a pioneer in the study of the feeble-minded.

\section{UNDER NAPOLEON I}

The history of the Maison Belhomme has carried us from the revolutionary into the Napoleonic period, when the traditions of the Revolution were continued. We will mention here only the cases of the political prisoners Montcarzain (interned in Charenton, 1805); Picot de la Clorivière (Maison Dubuisson after Temple et Vincennes, 1804); Geramb (Maison Mme. Dupeyron, 1812); Chodruc-Duclos (Bicêtre, 1811-1814). ${ }^{20}$ Charenton became officially a state prison again after $1807 . .^{21}$

It so happened that the most dangerous coup d'état ever attempted against Napoleon, that of General Malet on 23 October 1812, which in many ways resembles the 20 July 1944 incident in Germany, originated in one of these "mixed prisons called Maisons de Santé". ${ }^{22}$ Claude François de Malet was a republican general who wanted to save France by removing the tyrant. A first conjuration of 1808 brought him into the prisons La Force, Ste. Pélagie, and eventually into the Maison Dubuisson, $333 \mathrm{Fbg}$ St. Antoine. Here he was interned in 1810 with the royalist Abbé Lafon, with whom he organized the coup. Malet and Lafon escaped from the Dubuisson during the night, mobilized a regiment under the pretext that Napoleon had been killed in Russia and a new government formed, liberated other republican generals from La Force, succeeded in arresting the chief of police, and the minister and secretary of the interior, took over the Hôtel de Ville, but failed when attempting to arrest the military commander of the region. Malet, generals Lahory and Guidal, and eight other officers were court-martialled and shot. Asked by the judge for the names of his accomplices, Malet answered: "You, and all of France, if I had succeeded".

At that time the Maison Dubuisson was directed by Jean-Baptiste Remy-Jacquelin Dubuisson, who apparently was not molested after the coup, as he published his thesis on "Mania" in 1812 and a book on maladies mentales in 1816. He was born in Meulan in 1777, and began working with the insane around 1800. From his case histories it is clear that the Maison Dubuisson existed as early as 1769, apparently founded by his uncle C. H. Jacquelin Dubuisson, probably not a medical man, to whom he dedicates his thesis and whom he still quotes as his co-director in 1816.23 The younger Dubuisson was, like the younger Belhomme, a disciple of Esquirol, whom he also used as a consultant.

Together with the Empire, the barbarous custom of using psychiatric institutions for the internment of political prisoners disappeared from France; a turning-point not as spectacular as the removal of chains, but almost as important as an indication of a changed approach to both insanity and political opposition. ${ }^{23 a}$ The new private institutions created by psychiatrists under Napoleon or shortly thereafter (e.g. Esquirol 1801; Prost 1804; Blanche 1820; Falret et Voisin 1822, etc.) were never disgraced by such abuses. 


\section{E. H. Ackerknecht}

It seems obvious that the habit of housing political prisoners with lunatics or criminals in general neither derived from the wish to hide them (they were just as much hidden in "pure" political prisons); nor to torture them (treatment in psychiatric institutions tended to be a little milder); nor to defame them. Very rarely the argument was used that a prisoner was insane, as in the case of Latude, but in general internment in a mixed institution did not imply insanity. The government considered that all three categories needed internment: they were all "asocial" and, in the opinion of seventeenth-century rulers, not sufficiently different to merit confinement in separate institutions. The general hospital method seemed more practical and cheaper, especially when prison space was limited and much needed. When the community eventually acknowledged basic differences between the three groups, it also provided different places of internment for them.

It seems impossible not to mention here that apparently in the Soviet Union since the 1940s and especially the 1960s the internment of political opponents in psychiatric institutions, particularly in those for the criminally insane, has occurred. ${ }^{24}$ This new version of the methods of eighteenth-century absolutism is in many ways much worse. In the eighteenth century the political opponent was physically interned with the insane; but he was not stigmatized as insane. In twentieth-century Russia it seems that an attempt is being made to brand political opponents as lunatics. No medical man dishonoured himself and his profession during the eighteenth century by signing statements concerning political opponents allegedly suffering from "reform" schizophrenia or paranoia-it would have been called "reform-mania" or "reform-melancholy" then. It is certain that many Russian colleagues do not participate in these activities, and it is possible that some do believe internment in an institution to be kinder than in a labour camp.

Unfortunately, this technique of restraining political opponents may benefit from certain trends in modern thought and culture. Thirty years ago I drew attention to a phenomenon I then called "psycho-pathological labelling" which is the growing tendency to call an adversary "mentally ill" rather than "bad". ${ }^{25}$ With the increasing disappearance of common moral and religious criteria and the rising faith in science, such a weapon promises to be far more efficacious than the older epithets. It had sometimes been used earlier: Vesalius was once called "Vesanus" and not accidentally an old French proverb says: "Si tu veux tuer ton chien tu dis qu'il a la rage". But it became widespread after the mid-nineteenth-century discussions centring around the French Revolution, the enemies of which interpreted it as the work of psychotics, while its defenders specialized in the diseases of French kings. Our contemporary pro-Napoleon historian Gaubert regards Malet as insane! (Simultaneously a strange mental disease was discovered among Negro slaves in the U.S.A.: drapetomania, the compulsion to run away!)

It cannot be denied that sometimes the psycho-pathological label is protective. ${ }^{26}$ It is better to be a "hysteric" than a witch. But on the whole this pseudoscientific label is particularly dangerous and confusing. With the enormous prestige of science and the all-pervading tendency to interpret everything in psychological terms, called "iatro-psychology" by Jerome Schneck, it presents a worldwide danger. 


\section{Political prisoners in French mental institutions}

\section{REFERENCES}

1. E. H. Ackerknecht and K. Akert, 'Wechselnde Formen der Unterbringung von Geisteskranken', Schweiz. med. Wschr., 1964, 94: 1541-1546.

2. George Rosen, Madness in society, London, Routledge \& Kegan Paul, 1968, p. 163. L. Larguier, La Salpetrière, Lyons, 1939, p. 3. G. Guillain and P. Mathieu, La Salpetrière, Paris, Masson, 1925, p. 18. E. H. Ackerknecht, Medicine at the Paris Hospital 1794-1848, Baltimore, Johns Hopkins Press, 1967, p. 21.

3. Rosen, op. cit., note 2 above, p. 163.

4. F. Funck-Brentano and G. Marinaz, Bicêtre, Lyons, 1938, p. 25 ff. Larguier, op. cit., note 2 above, p. $6 \mathrm{ff}$. Guillain and Mathieu, op. cit., note 2 above, p. $36 \mathrm{ff}$.

5. Funck-Brentano and Marinaz, op. cit., note 4 above, p. 5.

6. Henri Masers de Latude, Mémoires, Paris, 1855.

7. Funck-Brentano and Marinaz, op. cit., note 4 above, p. 28.

8. H. Bonnafous-Sérieux, La Charité de Senlis, Paris, 1936, p. 13.

9. M. Foucault, Folie et deraison: histoire de la folie à l'âge classique, Paris, Librairie Plon, 1961, p. 481.

10. Rosen, op. cit., note 2 above, p. 168.

10a. H. R. Schwarz, Die medizinische Flagellation under besonderer Berücksichtigung von Meibom, Bartholin und Paullini, Zürich, Juris, 1963, p. 45. J. Robiquet, Saint Lazare, Lyons, 1938, p. 16.

11. D. Jetter, Geschichte des Hospitals, Band 2: 'Zur Typologie des Irrenhauses in Frankreich und Deutschland', Wiesbaden, F. Steiner, 1971, p. 40.

12. Bonnafous-Sérieux, op. cit., note 8 above, p. 67.

13. Ibid., p. 13.

14. G. Lenôtre, Paris révolutionnaire. Vieilles maisons, vieux papiers, 5 vols., Paris, 1924, vol. 1, p. 247.

15. A. Ferroni, 'Une maison de santé pour le traitement des aliénés à la fin du $18 \mathrm{e}$ siècle', Paris thesis, 1964, p. 23.

16. Lenôtre, op, cit., note 14 above, vol. 1, p. 331.

17. Ferroni, op. cit., note 15 above, p. 7.

18. Ibid., p. 23.

19. Concerning Belhomme, see Ferroni, op. cit,. note 15 above, and Lenôtre, op. cit., note 14 above, vol. 3.

20. Lenôtre, op. cit., note 14 above, vol. 4, p. 133; vol. 3, p. 214 ; vol. 2, p. 88; vol. 5, p. 337.

21. Jetter, op. cit., note 11 above, p. 40.

22. Jean-Baptiste-Hyacinthe Lafon, La conspiration du Général Malet, Paris, 1814, p. 20. For Malet's coup see H. Gaubert, Conspirateurs au temps de Napoleon I, Paris, 1962, pp. 291-343.

23. J. B. R. J. Dubuisson, Des vésanies ou maladies mentales, Paris, 1816, pp. 173, 285. R. Semelaigne, Les pionniers de la psychiatrie française, Paris, 1930, vol. 1, p. $110 \mathrm{ff}$.

23a. We have no French data on World War I, when the method was used in Germany (on $E$. Toller, O. M. Graf, etc.)

24. See e.g. G. Bortoli, Mort de Staline, Paris, 1973, pp. 172, 203. W. Bukowski, Opposition, eine neue Geisteskrankheit in der Sowjetunion, Munich, 1971. J. A. Medwedew and R. A. Medwedew, A question of madness, London, Macmillan, 1971. R. W. Schloss, Lass mein Volkziehen, Munich and Vienna, 1971.

25. E. H. Ackerknecht, 'Psychopathology, primitive medicine and primitive culture', Bull Hist. Med., 1943, 14: 30-67. (Reprinted in E. H. Ackerknecht, Medicine and ethnology, Berne, Huber, 1971, pp. 57-89.)

26. J. M. Bruttin, 'Différentes théories sur l'hystérie dans la première moitié du $19 \mathrm{e}$ siècle', Zürich thesis, 1969. E. Fischer-Homberger, 'Hysterie und Misogynie', Gesnerus, 1969, 26: 117. 